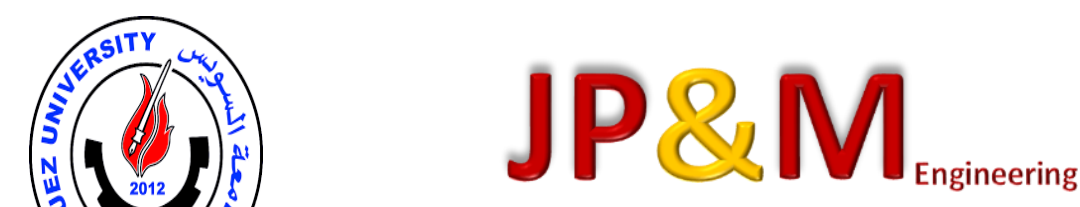

Journal of Petroleum and Mining Engineering

\title{
Effect of Partial Replacement of Iron Ore by Mill Scale on the Sinter Process
}

\author{
Saleh, A. B., ${ }^{*}$, Kahlifa M. G. ${ }^{b}$ and Abd Elmomen S. S. ${ }^{b}$ \\ a Egyptian Iron and Steel Company \\ b Tabbin Institute for Metallurgical Studies \\ Tabbin, Egypt, P.O. Box: 109 Helwan-11421 Cairo \\ * Corresponding author e-mail : belal geo2010@yahoo.com
}

\section{Article Info \\ Received: 15 Nov. 2020 Revised: 11 Mar. 2021 Accepted: 28 Apr. 2021}

\section{Keywords}

mill scale; sintering process; iron ore

\begin{abstract}
Mill scale is one of the byproducts which produced during the processing of steel.It is rich in iron( $\geq 70 \%$ ), has lower impurities and a stable chemical composition. The present research studies the effects of partial replacement of iron ore with different proportions of mill scale on the sinter charge. The results in this study showed that with an increase in iron ore substitution by mill scale at $3 \%$, the rate of production increases from 21.94 to 25.50 ton $/ \mathrm{m}^{2} /$ day (16.2\%), the vertical velocity increases from 0.0192 to $0.0217 \mathrm{~m} / \mathrm{min}(13 \%)$ and the strength of the produced sinter increases from $88 \%$ to $90 \%$ (2\%). Thus, the bulk density increases, but this negatively affects the reducibility degrees and apparent porosity of the produced sinter. At $2 \%$ mill scale, both reducibility and apparent porosity reach their highest values $(66.42,20.53 \%)$, respectively. On the other hand, the bulk density and softening interval decrease to the lowest values $\left(2.3 \mathrm{gm} / \mathrm{cm}^{3}, 70 \%\right)$, respectively.
\end{abstract}

\section{Introduction}

The Egyptian Iron and Steel Company (EISCO) as a first integrated steel plant in Egypt based on blast furnace and converter technology with a designed capacity of 30000 ton liquid steel /Year. It had two blast furnaces (BFs) having $575 \mathrm{~m}^{3}$ useful volume each. In the initial stages, Aswan iron ore was used to feed both blast furnaces. This ore is poor in iron and has high silica and phosphorous contents. In an expansion plant two larger (BFs) having $1033 \mathrm{~m}^{3}$ useful volume each were added in order to produce 1.5 million tons of liquid steel /year.

Bahariya iron ore was discovered and used in the form of self-fluxing sinter as BF feed. This ore is characterized by having relatively high iron content. However, it is relatively high in alkalis which cause many troubles in the sinter and BF plants [1]. It is worth to mention that both Iron ores, Aswan and Bahariya, have the same chemical formula $\left(\mathrm{Fe}_{2} \mathrm{O}_{3}\right)$ with different concentrations. EISCO has two sintering plants, sinter plant-I comprises two sintering machines (50m2 working area), and sinter plant-II contains five sintering machines $\left(75 \mathrm{~m}^{2}\right.$ working area each). The designed annual capacity of the sinter shop amounts to 3200000 tons. The produced sinter is low quality due to the relatively high content of alkalis which causes corrosion and failure of the equipment's in the sinter machine and the poor mechanical properties which are likely to cause operational problems in the blast furnaces such as pillaring, chammying, cold run of the furnace, hot run of the furnace, scaffolding and blocking of the hearth [1].

Mill scale is one of the byproducts produced during the processing of steel. It contains wustite ( $\mathrm{FeO}$ ), magnetite $\left(\mathrm{Fe}_{3} \mathrm{O}_{4}\right)$, and hematite $\left(\mathrm{Fe}_{2} \mathrm{O}_{3}\right)$, which is formed on the surface of steel as a result of oxidation of the metal during continuous casting, reheating and hot-rolling2). It is rich in iron ( $\geq 70 \%$ ), has lower impurities and a stable chemical composition and is often used in sintering process $[3,4]$. Some investigators found that the sinter strength initially increased and reached a maximum at mill scale addition of 40 to $50 \mathrm{~kg} / \mathrm{t}$-sinter but decreased thereafter $[4,5]$. It was also found that the reduction degradation index (RDI) and reducibility of the sinter decreased with the increasing mill scale addition which was attributed to the increase in $\mathrm{FeO}$ content.

The aim of the present work is to study the effect of partial replacement of iron ore by mill scale in order to improve the sinter process and sinter quality. 


\section{Experimental Work and Materials}

\section{Chemical Analysis}

The average chemical analysis of the raw materials used during the experiments (Bahariya ore, Limestone, Coke, Sinter return, and mill scale) were analyzed firstly by the traditional chemical analysis procedures, which give us the chemical composition whether it is Ferric or Ferrous. Then the raw materials were analyzed using XRF (Shimadzu-MXF 2400). Table (1) shows the achieved results.

Table 1: Average chemical analysis of raw materials used during the experiments

\begin{tabular}{|c|c|c|c|c|c|c|c|}
\hline & Iron & Limest & Dolom & Mill & Sinter. & Coke & Coke \\
\hline $\mathrm{Fe}_{\mathrm{Me}}$ & & & & 7 & & & \\
\hline $\mathrm{FeO}$ & & & & 50.41 & 9 & & \\
\hline $\mathrm{Fe}_{2} \mathrm{O}_{3}$ & 74.37 & & & 41.76 & 61.49 & & 25.78 \\
\hline $\mathrm{Fe}_{\mathrm{Tot}}$ & 52 & & & 75.4 & 50 & & 18.03 \\
\hline $\mathrm{SiO}_{2}$ & 9.98 & 0.59 & 7.42 & & 9.7 & & 37.93 \\
\hline $\mathrm{CaO}$ & 0.27 & 56.4 & 31.81 & 1.2 & 10.59 & & 7.81 \\
\hline $\mathrm{MgO}$ & 0.27 & 0.28 & 15.55 & 0.01 & 2.37 & & 2.18 \\
\hline $\mathrm{Al}_{2} \mathrm{O}_{3}$ & 1.1 & & & & 1.82 & & 14.17 \\
\hline $\mathrm{MnO}$ & 2.65 & & & 0.7 & 2.7 & & 1.06 \\
\hline $\mathrm{S}$ & 0.57 & & & 0.02 & 0.07 & 0.9 & \\
\hline $\mathrm{P}_{2} \mathrm{O}_{5}$ & 0.4 & & & 0.08 & 0.75 & & 0.77 \\
\hline $\mathrm{Cl}$ & 0.32 & & & 0.05 & 0.44 & & \\
\hline $\mathrm{BaO}$ & 0.35 & & & 0.02 & 0.41 & & 0.31 \\
\hline $\mathrm{ZnO}$ & 0.22 & & & 0.03 & 0.21 & & 0.18 \\
\hline $\mathrm{TiO}_{2}$ & 0.12 & 0.01 & 0.06 & & 0.15 & & 1.07 \\
\hline $\mathrm{Na}_{2} \mathrm{O}$ & 0.24 & 0.04 & 0.33 & 0.03 & 0.18 & & 0.42 \\
\hline $\mathrm{K}_{2} \mathrm{O}$ & 0.18 & 0.01 & 0.12 & & 0.12 & & 1.35 \\
\hline $\mathrm{LOI}$ & 9 & 42.35 & 43.55 & Gain & & & \\
\hline $\mathrm{R}_{2} \mathrm{O}_{3}$ & & 0.33 & 1.22 & & & & \\
\hline $\mathrm{SO}_{3}$ & & & & & & & 5.72 \\
\hline
\end{tabular}

The XRF analysis gives only the amount of $\mathrm{Fe}$ in the sample without any information whether it is $\mathrm{FeO}$ or $\mathrm{Fe}_{2} \mathrm{O}_{3}$. Therefore, we multiplied the amount of $\mathrm{Fe}$ by the factor of 1.43 to estimate the amount of $\mathrm{Fe}_{2} \mathrm{O}_{3}$. To calculate the amount of $\mathrm{FeO}$ in the sample, the sample is dissolved in $\mathrm{HCl}$. The insoluble residue is removed by filtration, ignited, treated for the recovery of iron, and added to the main solution. Then, $\mathrm{H}_{2} \mathrm{SO}_{4}$ is added, and the solution evaporated to fumes to expel chlorides. The salts are dissolved in water, the solution heated to boiling, and the iron reduced by a rapid stream of hydrogen sulfide $\left(\mathrm{H}_{2} \mathrm{~S}\right)$. The precipitated sulfides are filtered and washed with an acid-sulfide wash solution until free of iron. Then, the filtrate is boiled to expel the $\mathrm{H}_{2} \mathrm{~S}$, cooled, and titrated with $\mathrm{K}_{2} \mathrm{Cr}_{2} \mathrm{O}_{7}$ solution, using sodium diphenylamine sulfonate as the indicator, according to specification ASTM E246-10 2015.

\section{Sintering apparatus and sintering procedure}

The experiments were carried out using the research sinter pan as shown in Figure 1. It consists of a cylindrical steel tube with internal diameter of $250 \mathrm{~mm}$ and height of $350 \mathrm{~mm}$ ending with a grate having $3 \mathrm{~mm}$ aperture. This grate is mounted on a wind box which is connected with two high pressure fans in series.

The temperature of waste gases is determined by a thermocouple inserted in the path of the waste gases between the wind box and the suction fans connected to a temperature indication from $\left(0-1000{ }^{\circ} \mathrm{C}\right)$. There is an outlet to measure the amount of air withdrawn during operation. The maximum sucked air at the Pan of the research sector in maximum $400 \mathrm{~mm}$ water gauge. At the

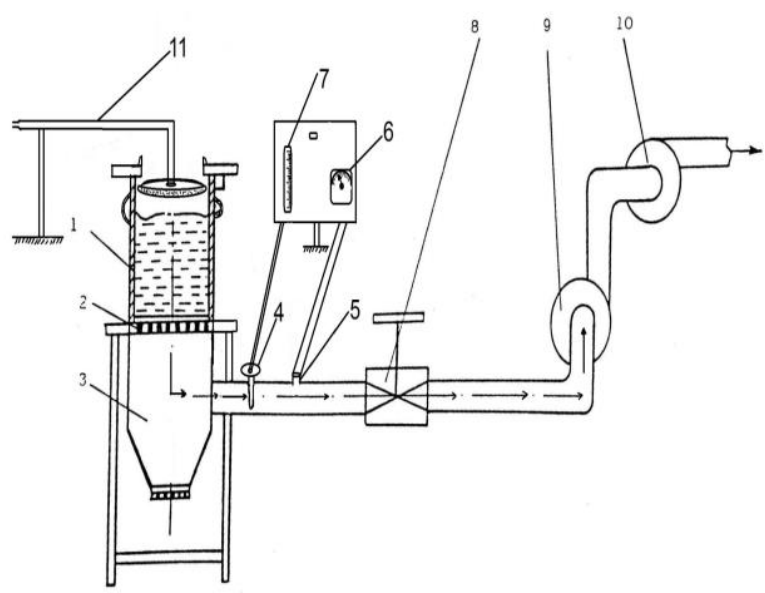

top of the cylindrical steel tube, the gas burners fixed to the beginning of the ignition surface.

Figure1: schematic diagram of pilot sinter pan

1 Sinter pot (steeltube)
2 Grate with aperture $3 \mathrm{~mm}$
3 Wind box
4 Thermocouple
5 Suction outlet

6 Indicator for withdrawal
7 Temperature indicators
8 Manual valves
9, 10 High pressure fads
11 Gas burner

The sizes of raw materials as follows Bahariya ore from (0$10 \mathrm{~mm})$, Coke from $(0.3-3 \mathrm{~mm})$, limestone from (0.2-3 $\mathrm{mm})$. The sinter basicity was 0.92 $(\mathrm{CaO}+\mathrm{MgO}) /\left(\mathrm{SiO}_{2}+\mathrm{Al}_{2} \mathrm{O}_{3}\right)$ which is within the permissible limits within the sintering sector of the Egyptian Iron and Steel Company, as the upper limit is $\mathbf{1 . 2}$ and the minimum is 0.70 .

The sinter charge was composed iron ore at $(55.67 \%)$, Coke rate at $(4.124 \%)$, limestone at $(6.186 \%)$, sinter return at (30.93\%) and moisture content as (12\%), mixed in a mixture for 4 minutes to make initial balls of sinter charge to increase the permeability of the charge. For each sintering experiment the rate of production ton $/$ day $/ \mathrm{m}^{2}$ and the sintering vertical velocity in $\mathrm{m} / \mathrm{min}$ are calculated for the used pilot sintering pan:

rate of production

$=\frac{\text { wt. of sinter }, \mathrm{t}}{\text { cross section area } \mathrm{m}^{2} \times \text { time to reach max . temp, day }}$

Vertical velocity

$=\frac{\text { height of bed before sintering }(\mathrm{m})}{\text { time to reach max. temp }(\min )}$

\section{Sinter Strength (Drum test)}

The apparatus used in the present work is that utilized for the abrasion testing of rock samples known as "Deval" apparatus. The sample weighting about 500gms of 
average grain size of $40 \mathrm{~mm}$ is charged to the two hollow cast iron cylinders closed at one end and furnished with a removable cover at the other. The cylinders are mounted on a rotating shaft at an angle of $30^{\circ}$ with the axis of rotation. The machine is rotated for 4.5 minutes at a rate of $36 \mathrm{rpm}$. At the completion of the test, the sample was screened on $5 \mathrm{~mm}$ sieve and the fraction over $5 \mathrm{~mm}$ is calculated in percent of the original weight and considered as an index for the sinter strength.

\section{Bulk Density and Apparent Porosity}

The selected sinter sample is placed in a tank filled with Kerosene.). Then, the sinter sample is removed and weighed while suspended in air $\left(W_{d}\right)$ and immersed in the Kerosene $\left(W_{c}\right)$. After that, the sample is placed in a dried oven with a temperature of $110^{\circ} \mathrm{C}$ until constant weight. Finally, the sample is placed in a desiccators and reweighed when cold $\left(W_{a}\right)[6]$.

$\mathrm{W}_{\mathrm{a}}=$ weight of dry test piece

$W_{d}=$ weight of the test sample suspended in air

$\mathrm{W}_{\mathrm{c}}=$ weight of the test sample immersed in liquid

$\mathrm{D}=$ density of the immersion liquid at the temperature that prevailed during the test

Bulkdensity $=\frac{W a}{W c-W d} \times D$

Apparentporosity, percent $=\frac{W c-W a}{W c-W d} \times 100$

\section{Reducibility}

It is one of the most important methods used to measure the reducibility, by determining the weight loss of the sample during the reduction process, which is the method used in this work. In this method, continuous measurement and recording is carried out from the beginning of the experiment to the end, the method of weight loss used in this work of the most accurate and simplest reduction methods. Figure (2) consisted of a vertical tube furnace, a thermo balance for monitoring the weight change of reacting sample temperature controller. The sample was placed in a nickel chrome crucible which suspended under balance by $\mathrm{Ni}-\mathrm{Cr}$ wire in hot zone. The furnace temperature was raised to the required temperature $\left(900^{\circ} \mathrm{C}\right.$ ) and maintained constant to $\pm 5^{\circ} \mathrm{C}$. A continuous flow of nitrogen gas for 5-7 $\mathrm{min}$, then hydrogen was allowed to pass through the reduction tube with fixed flow rate $1.5 \mathrm{~L} / \mathrm{min}$; the weight change of sample was recorded.

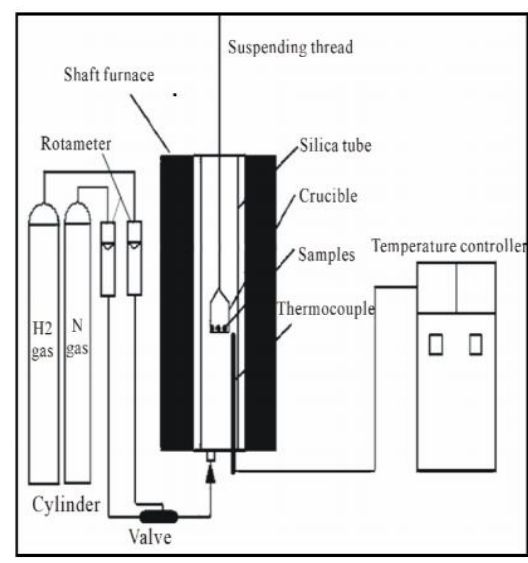

Figure 2 Thermo gravimetric Apparatus Used for the Reduction of sinter sample.

The percentage of reduction was calculated according to the following equation:

Degree of reduction $=\{(\mathrm{W} 0-\mathrm{Wt}) * 100\} /$ Oxygen (mass) $(5)$

where:

$W_{0}$ : the initial mass of sinter sample after removal of moisture.

$\mathrm{W}_{\mathrm{t}}$ : mass of sample at reaction time, $\mathrm{t}$.

Oxygen (mass): indicates the mass of oxygen percent in sinter in form $\mathrm{FeO}$ and $\mathrm{Fe}_{2} \mathrm{O}_{3}$

\section{Softening}

In this work, a device was used for measuring sinter softening and refractoriness under load in which the sinter sample is placed in a crucible of steel cylinder with a diameter of $40 \mathrm{~mm}$ and a height of $40 \mathrm{~mm}$. This process was done taking into account that the size of the sinter particles from +1 to $-3 \mathrm{~mm}$, then the sample (crucible) is placed inside the furnace. The device piston pressures the crucible which provides specific pressure equal to 2 $\mathrm{kg} / \mathrm{cm}^{2}$. At the end of the device piston, the pointer moving along the scale. The temperature is measured by thermocouple placed in contact with the crucible in the furnace. The furnace temperature is controlled by the transformer to heats the sample at a rate of $8-10^{\circ} \mathrm{C} / \mathrm{min}$, according to the heating rate in the blast furnace ${ }^{6}$. In the present investigation the softening interval with considered to be at shrinkage of $40 \%[7,8]$.

\section{Scanning Electron Microscope}

The morphology of the samples was observed by using scanning electron microscope (SEM) with FEI inspect SNetherlands

\section{Results and discussions \\ Effect of amount of mill scale replacement on FeO\%}

Table (2) and Figure (3) show the effect of replacing iron ore by different quantities of mill scale on $\mathrm{FeO} \%$. It is clear that the $\mathrm{FeO} \%$ in the produced sinter increases as mill scale 
increases; this may be due to an increase in the melt formation and magnetite during the sintering process [9].

Table 2: Chemical analysis of sinter samples prepared in different proportions from the mill scale.

\begin{tabular}{|c|c|c|c|c|}
\hline Sample & $\begin{array}{c}\text { Sinter (1) } \\
\text { (Baseline) }\end{array}$ & $\begin{array}{c}\text { Sinter (2) } \\
(1 \% \text { Millscale) }\end{array}$ & $\begin{array}{c}\text { Sinter (3) } \\
(2 \% \text { Millscale) }\end{array}$ & $\begin{array}{c}\text { Sinter (4) } \\
(3 \% \text { Millscale) }\end{array}$ \\
\hline $\mathrm{Fe}_{\mathrm{T}}$ & 49.80 & 50.80 & 51.20 & 52.80 \\
\hline $\mathrm{FeO}$ & 10.55 & 10.55 & 12.25 & 16.72 \\
\hline $\mathrm{Fe}_{2} \mathrm{O}_{3}$ & 59.48 & 60.91 & 59.6 & 56.91 \\
\hline $\mathrm{SiO}_{2}$ & 11.95 & 11.25 & 11.02 & 10.67 \\
\hline $\mathrm{CaO}$ & 9.87 & 9.32 & 8.95 & 8.80 \\
\hline $\mathrm{MgO}$ & 1.71 & 1.69 & 1.71 & 1.50 \\
\hline $\mathrm{Al}_{2} \mathrm{O}_{3}$ & 1.93 & 1.85 & 2.01 & 1.50 \\
\hline $\mathrm{MnO}$ & 2.50 & 2.40 & 2.29 & 2.14 \\
\hline $\mathrm{S}$ & 0.06 & 0.07 & 0.05 & 0.04 \\
\hline $\mathrm{P}_{2} \mathrm{O}_{5}$ & 0.62 & 0.59 & 0.60 & 0.54 \\
\hline $\mathrm{Cl}^{-1}$ & 0.16 & 0.18 & 0.14 & 0.13 \\
\hline $\mathrm{BaO}^{2 n O}$ & 0.46 & 0.48 & 0.55 & 0.40 \\
\hline $\mathrm{ZnO}$ & 0.19 & 0.17 & 0.18 & 0.16 \\
\hline $\mathrm{TiO}_{2}$ & 0.17 & 0.16 & 0.19 & 0.16 \\
\hline $\mathrm{Na}_{2} \mathrm{O}$ & 0.23 & 0.24 & 0.26 & 0.23 \\
\hline $\mathrm{K}_{2} \mathrm{O}$ & 0.12 & 0.15 & 0.11 & 0.10 \\
\hline
\end{tabular}

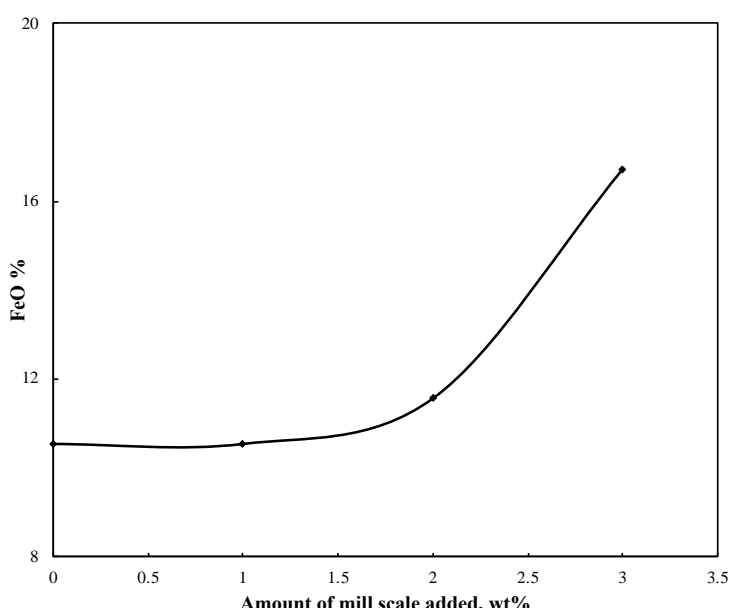

Figure 3: Effect of amount of mill scale replacement on $\mathrm{FeO} \%$

\section{Effect of amount of mill scale replacement on the vertical velocity of the sintering process}

Figure (4) shows the relationship between the vertical velocity of the sintering process and the quantity of the mill scale replacement, it is clear that with increasing amount of the mill scale the vertical velocity increases from 0.0192 to $0.0217 \mathrm{~m} / \mathrm{min}$. This may be due to improvement of the granulation process, which leads to improving of the sinter charge permeability during the sintering process [10].

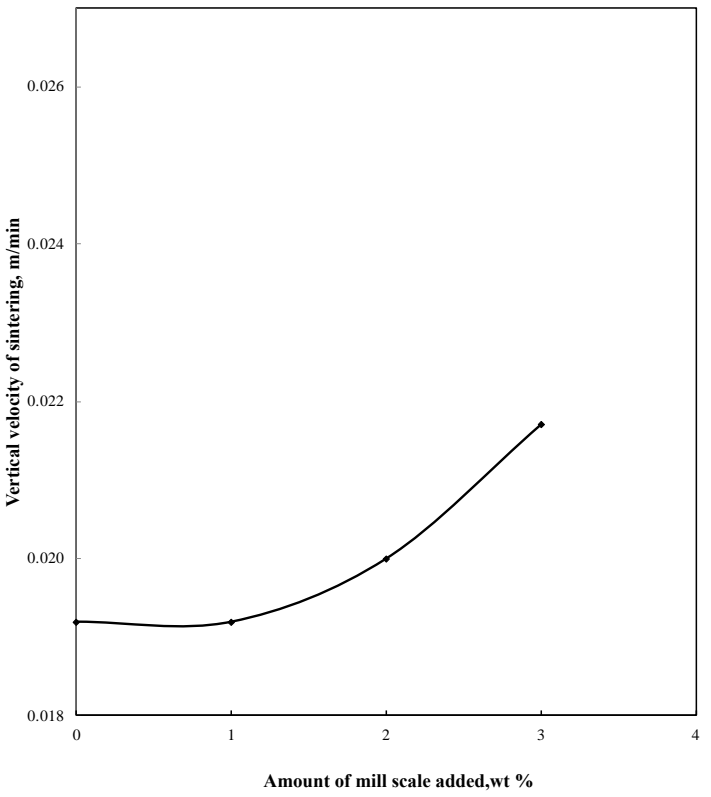

Figure 4: Effect of amount of mill scale replacement on the vertical velocity of the sintering process

Effect of amount of mill scale replacement on the sinter production rate

Figure (5) shows the effect of adding different quantities of mill scale on the sinter production rate. It is noted that by increasing the quantity of the mill scale replaced instead of iron ore, the sinter production rate increases from 21.94 to 25.50 ton $/ \mathrm{m}^{2} /$ day. This is due to the increase in the sinter strength and the vertical velocity of the sintering process ${ }^{5)}$.

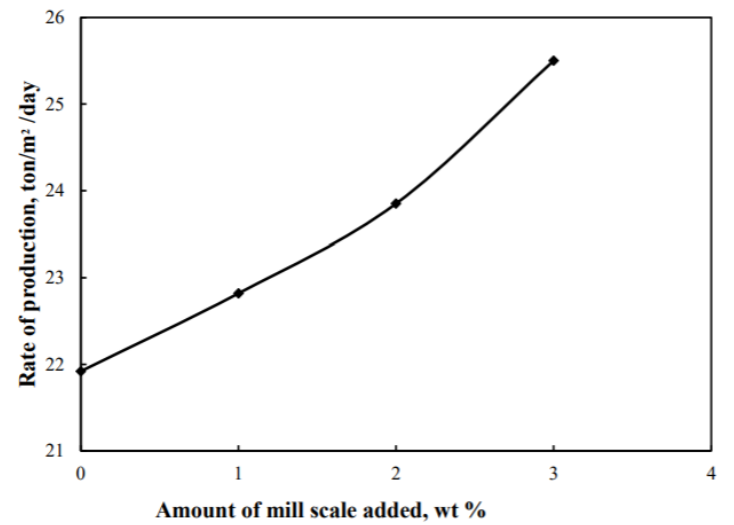

Figure 5: Effect of amount of mill scale replacement on the production rate of the sintering process

Effect of amount of mill scale replacement on the sinter strength

Figure 6 shows that the effect of adding different quantities of mill scale on the sinter strength, it is noted that by increasing the quantity of the mill scale replaced instead of iron ore the sinter strength increases from 88 to $90 \%(+5 \mathrm{~mm})$. It is observed that the temperature of the top layer of the sinter is increased by about $50{ }^{\circ} \mathrm{C}$ due to the exothermic reaction of iron and oxygen to $\mathrm{FeO}(1120$ $\mathrm{Kcal} / \mathrm{Kg})$ and $\mathrm{Fe}_{3} \mathrm{O}_{4}(1590 \mathrm{Kcal} / \mathrm{Kg})$ [11]. The increase in temperature resulted in the increase in the quantity melt formation and consequently increase in sinter strength. 


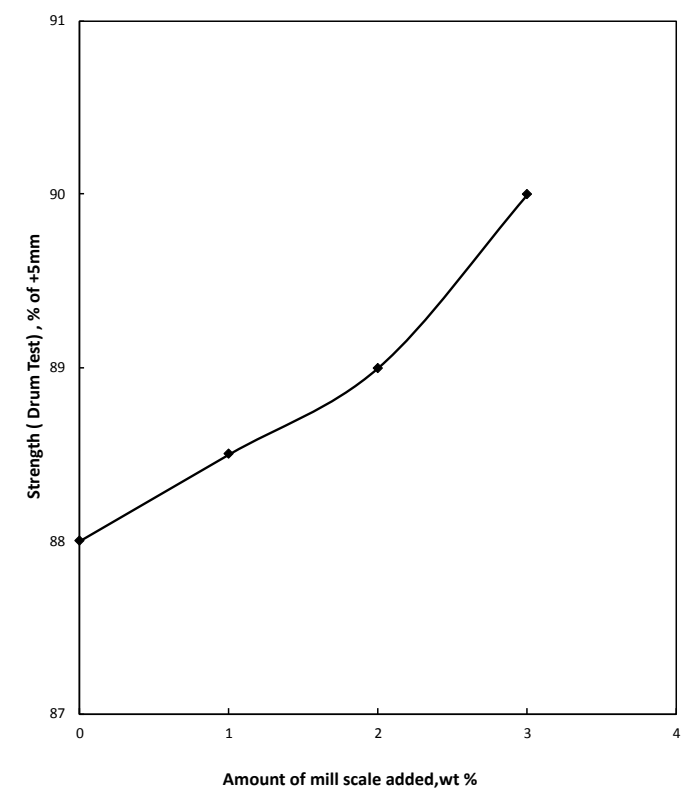

Figure 6: Effect of amount of mill scale replacement on sinter strength

Figure 7 shows that the hematite phase decreases with increasing mill scale up to $3 \%$, whereas magnetite and liquid phases increase. As shown in Table 1 and Figure 3, the increase of the amount of mill scale replaced instead of iron ore, resulted in the increase of the amount of $\mathrm{FeO}$.
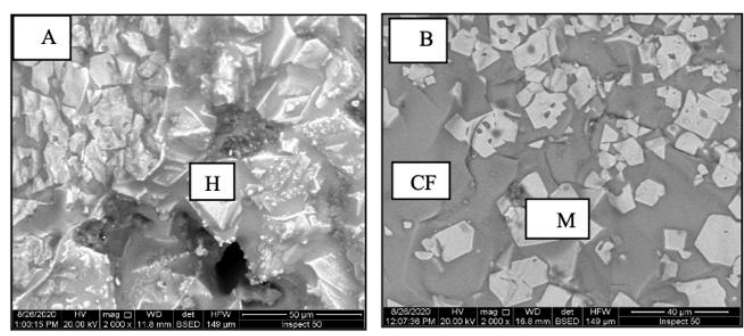

Figure 7 : SEM of the sinter sample,( A) $0 \%$ mill scale and (B) $3 \%$ mill scale

\section{Effect of amount of mill scale replacement on the apparent porosity and bulk density on the produced sinter}

Figures 8 and 9 show that the effect of adding different quantities of mill scale on the apparent porosity and bulk density of the produced sinter, shown that the apparent porosity of the produced sinter increases but bulk density decreases with the addition of mill scale up to (2\%). Addition of more than $2 \%$ mill scale causes decrease in the apparent porosity and increase in the bulk density of the produced sinter. This may be due to an increase the amount of melt formation.

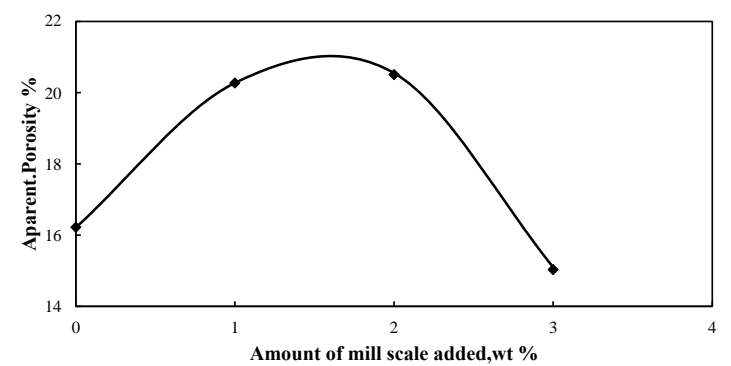

Figure 8: Effect of amount of mill scale replacement on apparent porosity of the sinter

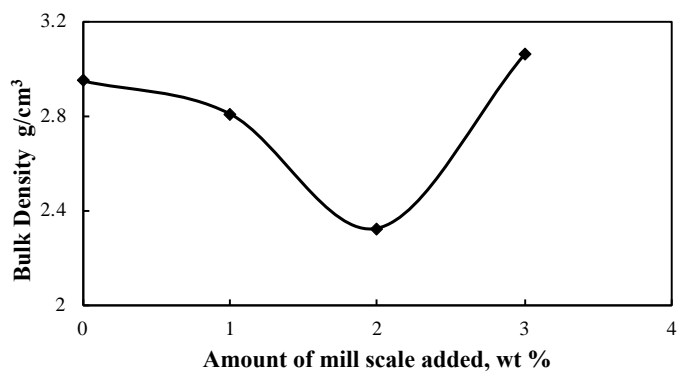

Figure 9: Effect of amount of mill scale replacement on bulk density of the sinter

Effect of amount of mill scale replacement on the reducibility of the sinter

At the same percentage of the mill scale $(2 \%)$, the reducibility of the sinter was recorded after 20 minutes with its highest value (66.42\%) as shown in Figure (10), addition of more than $2 \%$ of mill scale causes decrease the reducibility. This is due to the decrease in porosity of the produced sinter and increase in the amount of magnetite in the produced sinter as shown in Fig $(3,5$, and 8$)$ [9].

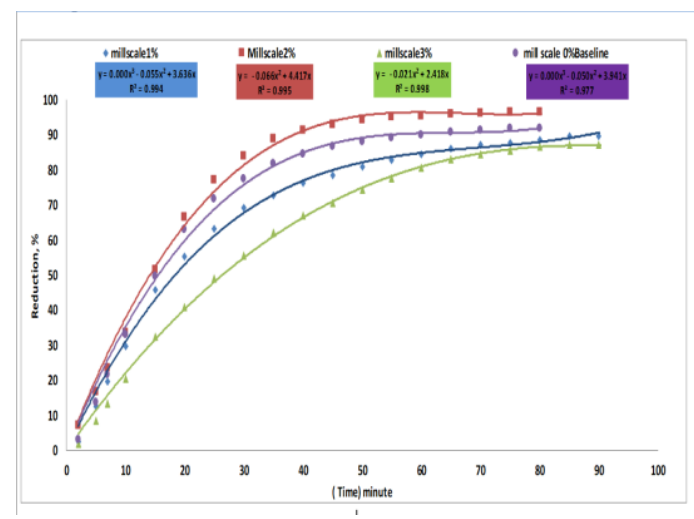

Figure 10: Effect of amount of mill scale replacement on reducibility of the sinter.

\section{Effect of amount of mill scale replacement on the softening interval of the sinter}

The lowest value of the softening interval $\left(70^{\circ} \mathrm{C}\right)$ appears at $2 \%$ mill scale replacement, with higher replacement with mill scale lead to an increase in softening interval as shown in Figure11. This may be due to the high content of FeO in sinter [12]. 


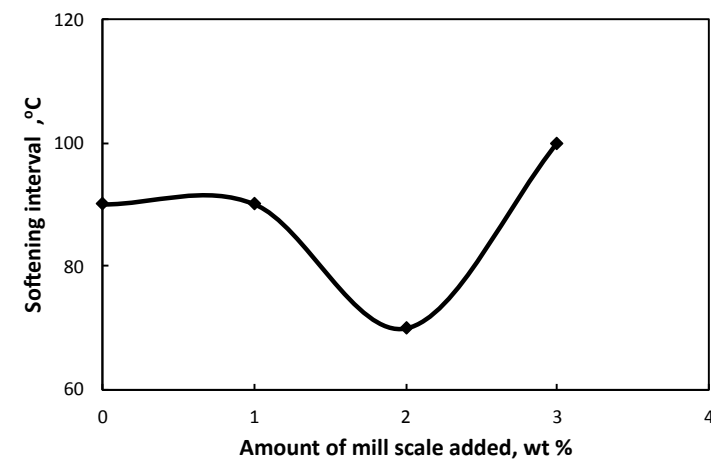

Figure 11: Effect of amount of mill scale replacement on Softening interval of the sinter

\section{Conclusions}

1. The replacing of $3 \%$ iron ore by the same amount of mill scale leads to:

- $\quad$ The strength of the sinter increases from 88 to $90 \%$ at $3 \%$ mill scale.

- The vertical velocity of the sinter increases from 0.0192 to $0.0217 \mathrm{~m} / \mathrm{min}$ at $3 \%$ mill scale.

- $\quad$ The sinter production rate increases from 21.94 to 25.50 ton $\backslash \mathrm{m}^{2} \backslash$ day.

2. The apparent porosity of the produced sinter increases but bulk density decreases with the addition of mill scale up to $(2 \%)$.

3. The reducibility of the sinter reaches its highest value $(66.42 \%)$ at $2 \%$ mill scale and then decreases with higher replacement.

\section{Acknowledgments:}

The authors wish to thank the Egyptian Iron and Steel Company (EISCO) for conducting the sinter experiments and Tabbin Institute for Metallurgical studies for the use of SEM.

\section{References}

[1] M. Meraikib:Stahl U.Eisen,102, 1269, (1982) (in Germany).

[2] N. Birks, G.H. Meier, and F.S. Pettit: Introduction to the High Temperature Oxidation of Metals, 2nd ed., Cambridge University Press, Cambridge, (2006).

[3] T. Umadevi, M.G.S. Kumar, P.C. Mahapatra, T.M. Babu, and M.Ranjan: Ironmaking. Steelmaking, 36, 409, (2009).

[4] T. Umadevi, A. Brahmacharyulu, P. Karthik, P.C. Mahapatra, M.Prabhu, and M. Ranjan: Ironmaking. Steelmaking, 39, 222, (2012).

[5] N.A. El-Hussiny, F.M. Mohamed, and M.E.H. Shalabi: Sci. Sinter.,43, 21, (2011).

[6] J.H.Chesters, Refractories, "production and properties", Iron and steel institute, London, (1973).

[7] H.W.Gudenau, K. Kreibich,Y. Nomiya:Stahl und Eisen, 100, 488, (1980).

[8] K. Ono, K. Yamaguchi, A. Shigemi, Trans : ISIJ int.,20, 357, (1980).

[9] H.Li-Heng:ISIJ int., 45, 551, (2005).

[10] L.X.Yang: ISIJ int., 45, 469, (2005).

[11] A. Bandopadhyay,A.Ganguly, K.K.Prasad, S.B.Sarkar and H.S.Ray:ISIJ int.,29, 753, (1989).

[12] V.Shatokha, O.Velychko:Mater. Proc., 31, 215 (2012).

\section{Funding sources}

The Egyptian Iron and Steel Company

\section{Conflicts of interest}

There is no conflict of interest. 